\title{
Maternal and fetal outcome among pregnant women presenting with thrombocytopenia
}

\author{
Vikrant Chauhan, Amit Gupta*, Neelam Mahajan, Anju Vij, Rajinder Kumar, \\ Abhinav Chadda
}

Department of Obstetrics and Gynaecology, Dr. Rajendra Prasad Government Medical College Kangra, Tanda, Himachal Pradesh, India

Received: 16 June 2016

Revised: 08 July 2016

Accepted: 09 July 2016

*Correspondence:

Dr. Amit Gupta,

E-mail: dramit203@yahoo.com

Copyright: () the author(s), publisher and licensee Medip Academy. This is an open-access article distributed under the terms of the Creative Commons Attribution Non-Commercial License, which permits unrestricted non-commercial use, distribution, and reproduction in any medium, provided the original work is properly cited.

\begin{abstract}
Background: Thrombocytopenia complicates about 7-8\% of all pregnancies. It is an under-explored condition in Indian women during pregnancy, so the study was planned to find out the prevalence and causative factors of thrombocytopenia during pregnancy and to review management strategies for the best feto-maternal outcome.

Methods: This prospective study was conducted in the department of obstetrics and gynecology at Dr. Rajendra Prasad Government Medical College Kangra at Tanda, Himachal Pradesh. 546 antenatal women were screened, 65 women who were diagnosed with thrombocytopenia, were included in the study.

Results: The incidence of maternal thrombocytopenia in our study was $8.4 \% .63 \%$ of the women had mild thrombocytopenia while $35.4 \%$ and $1.5 \%$ of women were moderate and severe thrombocytopenic respectively. The mean maternal platelet count was $106907 \pm 30136.52 / \mu \mathrm{L}$ whereas the mean neonatal platelet count was $175307.7 \pm 33834.87 / \mu \mathrm{L}$. The incidence of fetal thrombocytopenia was 3.1\%. Amongst 65 thrombocytopenic women $1.5 \%$ had HELLP Syndrome, $26.3 \%$ had PIH and $68.2 \%$ had gestational thrombocytopenia. $27.7 \%$ were delivered by LSCS and $72.3 \%$ were delivered vaginally. The most common indication of LSCS was acute fetal distress with MSL $(55 \%)$ followed by breech $(25 \%)$, failed induction (10\%), and the rest (10\%) for other obstetrical indications. $30 \%$ women required induction of labor with misoprostol for various obstetrical indications. The most common indication for induction was mild pre-eclampsia (45\%) followed by IUGR (25\%), PROM (15\%) and post-date (15\%).

The mean baby weight in our study was $2.84 \pm 0.32 \mathrm{~kg}$. Out of 65 neonates, $6.15 \%$ neonates required NICU admission. One neonate died at first post - op day because of respiratory distress syndrome. APGAR score $<7$ in 1 and 5 min were seen in $6.15 \%$ of neonates. Only $8 \%$ neonates were small for gestational age.

Conclusions: In pregnancy with thrombocytopenia, gestational thrombocytopenia is the commonest and benign condition which does not alter the obstetrical management. Still a vigil should be kept on maternal platelet count in antenatal period to prevent unfavorable outcome in serious conditions that may require specific and urgent management (HELLP syndrome, severe pre-eclampsia, TTP, HUS and acute fatty liver of pregnancy).
\end{abstract}

Keywords: Thrombocytopenia, Pregnancy induced hypertension, HELLP Syndrome

\section{INTRODUCTION}

Thrombocytopenia is defined as platelet count less than $150000 / \mu \mathrm{L}{ }^{1,2}$ It is second only to anemia as the most common hematological abnormality encountered during pregnancy. Thrombocytopenia or low blood platelet count is encountered in $7-8 \%$ of all pregnancies. Obstetricians diagnose thrombocytopenia by automated complete blood cell counts during routine prenatal screening. ${ }^{3}$ 
It can result from a wide range of conditions, several of them being pregnancy related. ${ }^{1}$ The normal range of platelets in non-pregnant women is $150,000-400,000 / \mu \mathrm{L}$. Average platelet count in pregnancy is decreased $(2,13,000 / \mu$ l versus $2,50,000 / \mu \mathrm{L})$. Decrease in the platelet count is due to hemodilution, increased platelet consumption, and increased platelet aggregation driven by increased levels of thromboxane A2.

- Mild thrombocytopenia is $1,00,000-1,50,000 / \mu \mathrm{L}$

- Moderate thrombocytopenia is $50,001-1,00,000 / \mu \mathrm{L}$

- Severe thrombocytopenia is less than $50,000 / \mu \mathrm{L}^{4}$

Clinical assessment is the most important factor for the evaluation of a pregnant patient with thrombocytopenia. Medical history may include the following:

- Current or previous bleeding problems

- Family history of bleeding

- Alcohol or substance abuse history

- Past obstetrical history, transfusion history.

Examination findings suggestive of thrombocytopenia include the following: petechiae, ecchymosis, nose and gum bleeding, hematuria, gastrointestinal bleeding, intracranial bleeding. The etiologic classification for thrombocytopenia can be divided into 2 broad categories:

- Obstetric (gestational thrombocytopenia, hypertensive disorders, DIC, multifetal gestation etc).

- Non Obstetric (ITP, hypersplenism, hepatic disorders, Iatrogenic etc).

\section{Gestational thrombocytopenia}

The incidence of gestational thrombocytopenia is $8 \%$ of all pregnancies and accounts for more than $75 \%$ of cases of thrombocytopenia in pregnancy. ${ }^{3}$ Platelet counts normalize within 2-12 weeks following delivery. Burrows and Kelton in 1990 reported that all women with gestational thrombocytopenia had normal platelet counts by the seventh postpartum day. ${ }^{5}$ No pathological abnormality for the mother or fetus was noted in gestational thrombocytopenia.

\section{Pre-eclampsia/eclampsia}

Preeclampsia accounts for $21 \%$ of cases of maternal thrombocytopenia. ${ }^{5}$ Thrombocytopenia is usually moderate to severe. Platelet count rarely decreases to $<20,000 / \mu \mathrm{L}$.

The most severe spectrum of preeclampsia is established when the vascular endothelial damage produces microangiopathic hemolytic anemia, elevating liver enzymes along with thrombocytopenia and establishing a syndrome known as HELLP (hemolysis, elevated liver enzymes, low platelets). Hypertensive disorders occur in
7-10\% of all pregnancies and HELLP complicates 4-12\% of all women with preeclampsia. ${ }^{4}$ Neonates may be at increased risk for thrombocytopenia.

\section{Immune thrombocytopenic purpura}

It is also known as idiopathic thrombocytopenic purpura or autoimmune thrombocytopenic purpura (ATP). Its incidence is 1 per $1,000-10,000$ pregnancies and it accounts for $3 \%$ of all thrombocytopenic gravidas. ${ }^{6}$ It causes significant fetal thrombocytopenia $(<50,000 / \mu \mathrm{L})$, as antiplatelet antibodies may cross the placenta which could result in bleeding complications in the neonate.

\section{Pseudo-thrombocytopenia}

Pseudo-thrombocytopenia is a spuriously low platelet count due to laboratory artefact. No treatment of pseudothrombocytopenia exists.

\section{Microangiopathies}

Thrombotic thrombocytopenic purpura (TTP) and hemolytic uremic syndrome (HUS) are characterized by thrombocytopenia, hemolytic anemia, and multiorgan failure. Microangiopathies are often mistaken for preeclampsia/HELLP, often leading to delay in diagnosis and treatment. Etiology is unknown, but endothelial damage is suspected as the initiator. Differentiation between TTP, HUS, and HELLP can be difficult or even impossible, especially when the onset is in the second or third trimester. Delivery leads to resolution but the condition may continue or worsen after delivery with TTP/HUS.

\section{Hypersplenism}

Congestion of the spleen results in sequestration of platelets. Hypersplenism often is observed in association with cirrhosis of the liver. Well-known agents that cause thrombocytopenia include heparin, zidovudine (ZDV), and sulfonamides. Almost all medications can result in transient thrombocytopenia7.

\section{Viral illnesses}

Cytomegalovirus (CMV) and human immunodeficiency virus (HIV) are well-known causes, although almost all viruses can result in thrombocytopenia.

\section{Disseminated intravascular coagulation}

Disseminated intravascular coagulation (DIC) is usually associated with bleeding. It is observed obstetrically with abruption and postpartum hemorrhage and associated with low fibrinogen, elevated fibrinogen degradation products, and the presence of D-dimers. 


\section{Alloimmune thrombocytopenia}

Alloimmune thrombocytopenia represents the most common cause for profound fetal/neonatal thrombocytopenia and intracranial hemorrhage in the infant. Alloimmune thrombocytopenia has no effect on maternal platelet counts.

Thrombocytopenia during pregnancy is an underexplored condition in Indian women, so the study was planned to find out the prevalence and causative factors of thrombocytopenia during pregnancy and to review management strategies for the best feto-maternal outcomes.

The objective of this study was to study the maternal and fetal outcome among pregnant women presenting with thrombocytopenia.

\section{METHODS}

This prospective study design was carried out in department of obstetrics and gynecology at Dr. Rajendra Prasad Government Medical College, Tanda, District Kangra, Himachal Pradesh, India. for a period of one year June 2014 to May 2015.

All consenting females who attended UNIT III OPD over a period of one years from June 2014 to May 2015 (546 cases).

\section{Inclusion criteria}

All pregnant women with platelet count less than $1,50,000 / \mu \mathrm{L}$ and who were willing to participate in the study were enrolled for study over a period of one year (June 2014 to May 2015). 546 antenatal mothers were subjected to platelet count, maternal and fetal outcome was studied in 65 women who were diagnosed with thrombocytopenia after the gestational age of 28 weeks.

The collection of sample was after taking informed consent of participant, blood specimen was withdrawn from the ante-cubital vein using a dry sterile disposable syringe and needle. $2 \mathrm{ml}$ of blood was dispensed into EDTA anticoagulant tube. The specimens were labeled with subject's name, age, sex and C.R. number, and sent to laboratory for platelet count estimation.

\section{Exclusion Criteria}

\section{Women with known history of}

- Diabetes mellitus

- Collagen disorders

- Tuberculosis

- Epilepsy and

- Previous bad obstetric histories.

\section{Methodology}

Antenatal women were enrolled in the study in third trimester. All women had platelet count estimation at the time of enrolment. Platelet count assessment was done through automated blood count analyzer with routine antenatal hematological evaluation of the patient. Demographic features, detailed history, presenting complaints if any, findings of general, systemic and obstetrical examination including pelvic examination if required of all the patient were recorded in approved proforma. Baseline investigations like complete haemogram, blood group and Rh typing, O'sullivan's test, urinalysis, VDRL, HBsAg and HIV serology were carried out in all subjects. Special investigations like coagulation profile (PT, APTT, FDP and fibrinogen) KFT and LFT were done if clinically indicated. Any other investigation was done as and when required. The detailed work up of all cases was done to ascertain the cause of thrombocytopenia. History of petechiae, bruising, drug usage, viral infection, thrombocytopenia in previous pregnancy was taken. The data was collected on printed proforma which included clinical details regarding demographic data, presenting complaints, obstetric and menstrual history, symptoms of thyroid dysfunction, associated medical illness like hypertension, or other cardiovascular diseases, diabetes mellitus, drug history and general physical examination, systemic examination, obstetrical examination including pelvic examination was done. Gestational age was established by menstrual history and clinical examination and confirmed by USG.

All the cases were followed till delivery to record any complications like preterm labour, abruption, preeclampsia, any other morbidity. Duration of pregnancy at the time of delivery, indication of induction and method (if required) and mode of delivery including indication for instrumental delivery or caesarean section were recorded. Progress of labor was monitored partographically. Neonates of all cases were tested for thrombocytopenia by cord blood sampling. All women enrolled were followed up by estimation of platelet count on 10th days postpartum.

\section{Statistical analysis}

Standard statistical methods were used for analyzing the data.

\section{RESULTS}

A prospective study was conducted in the department of obstetrics and gynecology, Dr. RPGMC Tanda, Kangra (Himachal Pradesh) from June, 2014 to May 2015 on 65 pregnant women with singleton pregnancy with period of gestation 28 weeks onwards, who attended UNIT-III OPD and were found to have thrombocytopenia after screening. The women who were willing to participate in 
the study and who fulfilled the inclusion criteria were enrolled in the study after taking informed consent.

Most of the women were less than 30 years (98.5\%) and only one woman was more than 35 years old. The mean age in our study was $25.45 \pm 3.87$ years.

The mean platelet count was 106907 $\pm 30136 / \mu \mathrm{L}$. Majority of women had mild thrombocytopenia (63.1\%). $35 \%$ women had moderate thrombocytopenia and only one had severe thrombocytopenia.

Table 1: Distribution of women according to platelet count.

\begin{tabular}{|lll|}
\hline Platelet count & Number & Percentage \\
\hline $\begin{array}{l}\text { Mild 100000- } \\
149999\end{array}$ & 41 & $63.1 \%$ \\
\hline $\begin{array}{l}\text { Moderate 50000 } \\
-99999\end{array}$ & 23 & $35.4 \%$ \\
\hline Severe <50000 & 1 & $1.5 \%$ \\
\hline $\begin{array}{l}\text { Mean platelet } \\
\text { count }\end{array}$ & $106907 \pm 30136 / \mu \mathrm{L}$ & $100 \%$ \\
\hline
\end{tabular}

Association of thrombocytopenia with other medical illness was evaluated in our study. It was found that anemia was associated in 5 women, two women had ITP and hypothyroidism was found in only one woman. Rest all women have no diagnosed other medical illness.

Table 2: Distribution of women according to relation with other medical illness.

\begin{tabular}{|lll|}
\hline Related medical illness & Number & Percentage \\
\hline None & 57 & $87.8 \%$ \\
\hline Anemia & 5 & $7.6 \%$ \\
\hline ITP & 2 & $3.1 \%$ \\
\hline Hypothyroidism & 1 & $1.5 \%$ \\
\hline
\end{tabular}

As depicted in literature various drug are associated with thrombocytopenia, so history of drug intake was taken from all women who were enrolled in the study, none of women had history of drug intake related to thrombocytopenia

In our study it was found that PIH was associated with $26.2 \%$ of thrombocytopenic women. Among the 17 women who had PIH, majority of them had gestational hypertension in $64.9 \%$ followed by pre-eclampsia in $23.5 \%$. Severe pre-eclampsia was noted in one $(5.8 \%)$ woman. Only one had eclampsia $(5.8 \%)$.

Table 3: The distributions of women based upon association with PIH.

\begin{tabular}{|lll|}
\hline Association & Number & Percentage \\
\hline With PIH & 17 & $26.2 \%$ \\
\hline Without PIH & 48 & $73.8 \%$ \\
\hline Total & $\mathbf{6 5}$ & $\mathbf{1 0 0 \%}$ \\
\hline
\end{tabular}

As thrombocytopenia is associated with HELLP syndrome. However, out of 65 women in our study only one had HELLP syndrome. Her platelet count was 60000 and SGOT was 400 and SGPT was 326. Table 13 show the association with HELLP syndrome.

Table 4: Distribution of women based upon association with PIH.

\begin{tabular}{|ll|l|}
\hline PIH & Number & Percentage \\
\hline Gestational hypertension & 11 & $64.9 \%$ \\
\hline Pre-eclampsia & 4 & $23.5 \%$ \\
\hline Severe Pre-eclampsia & 1 & $5.8 \%$ \\
\hline Eclampsia & 1 & $5.8 \%$ \\
\hline
\end{tabular}

Out of 65 women, 20 women $(30 \%)$ were induced for various indications. Majority of women (45\%) were induced for post-dated pregnancy. Rest were induced for pre-eclampsia (15\%), PROM (25\%) and IUGR (15\%).

Out of 65 women, $27.7 \%$ had caesarean section for various maternal and fetal indications and majority of women $(72 \%)$ had normal vaginal delivery.

Table 5: Indications of LSCS.

\begin{tabular}{|lll|}
\hline Indication of LSCS & $\begin{array}{l}\text { Number } \\
(\mathrm{N}=20)\end{array}$ & Percentage \\
\hline MSL with fetal distress & 11 & $55 \%$ \\
\hline Breech & 5 & $25 \%$ \\
\hline Failed induction & 2 & $10 \%$ \\
\hline $\begin{array}{l}\text { Previous LSCS with } \\
\text { impending scar rupture }\end{array}$ & 1 & $5 \%$ \\
\hline Type 4 placenta previa & 1 & $5 \%$ \\
\hline
\end{tabular}

The mean weight of neonates born to the women enrolled in our study was $2.84 \pm .32 \mathrm{~kg}$, majority of new born $(92.3 \%)$ had weight appropriate for gestational age and only $7.7 \%$ were small for gestational age. None of neonate was large for gestational age.

Out of 20 neonates born by caesarean section, 4 were admitted in NICU for various indications. Mean APGAR score at 1 minute and 5 minutes was $7.29 \pm 1.78$ and $9.29 \pm 1.14$ respectively. Four neonates developed jaundice after caesarean section. 4 neonates who were admitted in NICU had APGAR score less than 7 at 5 minutes.

Table 6: Distribution based upon neonatal complication.

\begin{tabular}{|lll|}
\hline $\begin{array}{l}\text { Neonatal } \\
\text { complication }\end{array}$ & $\begin{array}{l}\text { Number } \\
(\mathrm{N}=65)\end{array}$ & Percentage \\
\hline Jaundice & 4 & $6.2 \%$ \\
\hline $\begin{array}{l}\text { Respiratory distress } \\
\text { syndrome }\end{array}$ & 1 & $1.53 \%$ \\
\hline No complication & 60 & $92.30 \%$ \\
\hline
\end{tabular}


Early neonatal death was observed in one neonate, neonate born to women who had eclampsia, died on 1 st post-operative day due to respiratory distress syndrome.

After delivery, platelet count of all the neonates of the mothers enrolled for study was done. Out of 65 neonate, 63 had platelet count more than $150000 / \mu \mathrm{L}$ and only 2 neonates had thrombocytopenia with platelet count between $1,00,000$ to $1,49,999 / \mu \mathrm{L}$.

Table 7: Neonatal platelet count.

\begin{tabular}{|lll|}
\hline Neonatal platelet count & $\begin{array}{l}\text { Number } \\
(\mathrm{N}=65)\end{array}$ & Percentage \\
\hline$>150000$ & 63 & $96.9 \%$ \\
\hline $100000-149999$ & 2 & $3.1 \%$ \\
\hline
\end{tabular}

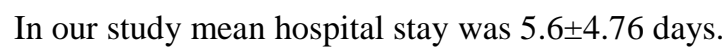

\section{DISCUSSION}

Most of the patients with mild thrombocytopenia do not alter the obstetrical management but at times severe thrombocytopenia, in life threatening conditions like HELLP syndrome, poses a great challenge to the treating obstetrician.

In present study the incidence of maternal thrombocytopenia was $8.40 \%$ which was comparable to the studies by Dwivedi et al $(8.17 \%)$, Vyas et al $(7.60 \%)$ Burrows et al $(7.60 \%)$ and Singh et al $(8.80 \%)$. $^{8-11}$ However, the incidence of thrombocytopenia was higher in the studies by Ajibola et al $(13.50 \%)$ and Onisai et al $(11.11 \%){ }^{12,13}$ Lower incidence was noted in the study of Brohi et al (1.90\%) and Lin et al $(4.30 \%) .{ }^{14,15}$

Table 8: Comparison of studies according to incidence of maternal thrombocytopenia.

\begin{tabular}{|c|c|c|c|}
\hline Study & Incidence & P value & Significance \\
\hline Dwivedi et $\mathrm{al}^{8}$ & $8.17 \%$ & 0.861 & NS \\
\hline${\text { Vyas et } \mathrm{al}^{9}}^{9}$ & $7.6 \%$ & 0.491 & NS \\
\hline Burrows et al ${ }^{10}$ & $7.6 \%$ & 0.483 & NS \\
\hline Singh et al $^{11}$ & $8.8 \%$ & 0.797 & NS \\
\hline Ajibola et $\mathrm{al}^{12}$ & $13.5 \%$ & 0.023 & $\mathrm{~S}$ \\
\hline Onisai et al $^{13}$ & $11.11 \%$ & 0.098 & NS \\
\hline${\text { Brohi et } \text { al }^{14}}^{14}$ & $1.9 \%$ & 0.000 & HS \\
\hline Lin et $\mathrm{al}^{15}$ & $4.3 \%$ & 0.000 & HS \\
\hline Present study & $8.4 \%$ & & \\
\hline
\end{tabular}

The mean age of patients in present study was $25.74 \pm 3.86$ years. In a study by Suri et al the mean age was a little higher i.e. 27 years. ${ }^{16}$ In study by Borna et al, Turgot et al, Jaleel et al mean age of patient was 28, 27.6 \pm 5.7 and 28.43 respectively. ${ }^{17-19}$ Where as in a study by Ruggri et al the mean age was higher i.e. $32 .^{20}$ The mean age was also higher in the study of Parnas et al i.e 30 years. $^{21}$ This might be due to fact that these studies were conducted in
European countries where general age of marriage is high.

The mean BMI of patient in our study was $20.95 \pm 2.09$ $\mathrm{kg} / \mathrm{m}^{2}$. Lin et al study also had similar BMI i.e. 20.5. ${ }^{15}$ However in the study by Nazli et al mean BMI was $30.96 \pm 1.08$ higher than our study. ${ }^{22}$

In present study the enrolled women's gravidity was $1.6 \pm 0.78$. In the study by Dwivedi et al the mean gravidity was $2.15 \pm 0.99$ which was higher than our study. ${ }^{8}$

In our study $53.8 \%$ of patients were primigravida and $46.02 \%$ were multigravida. Similar distribution of patient was seen in study by Bhatet al $(65 \%)$ and Won et al $(51.6 \%)$, whereas in the study by Brohi et al $40.8 \%$ women were primigravida, which was slightly lower than our study. ${ }^{14,23,24}$

In our study $63.2 \%$ women had mild thrombocytopenia. However, mild thrombocytopenia was noted in $54 \%$ and $74.7 \%$ patients included in the study by Borna et al which is lower than our study and Singh et al respectively. ${ }^{11,17}$ Singh et al reported a higher incidence of thrombocytopenia i.e. $74.4 \%$ as compare to our study and the difference was statistically significant. ${ }^{11}$

In our study $35.4 \%$ patient had moderate thrombocytopenia which is similar to study conducted by Borna et al (30\%) whereas in study by Singh et al moderate thrombocytopenia was seen in less number of patient i.e. $17.9 . \% .^{11,17}$

In the present study severe thrombocytopenia was seen in $1.5 \%$ of patient where as in study of Borna et al and Singh et al severe thrombocytopenia was seen in higher percentage of patients ( $16 \%$ and $7.4 \%$ respectively). ${ }^{11,17}$

Table 9: Comparison of studies according to severity of maternal thrombocytopenia.

\begin{tabular}{|lllllll|}
\hline Study & Mild & Moderate & Severe & $\begin{array}{l}\text { P } \\
\text { value }\end{array}$ & Significance \\
\hline $\begin{array}{l}\text { Singh } \\
\text { et al }^{11}\end{array}$ & $74.7 \%$ & $17.9 \%$ & $7.4 \%$ & 0.017 & $\mathrm{~S}$ \\
\hline $\begin{array}{l}\text { Borna }^{17} \\
\text { et al }\end{array}$ & $54 \%$ & $30 \%$ & $16 \%$ & 0.019 & $\mathrm{~S}$ \\
\hline $\begin{array}{l}\text { Present } \\
\text { study }\end{array}$ & $63.1 \%$ & $35.4 \%$ & $1.5 \%$ & & \\
\hline
\end{tabular}

In present study mean gestation age at delivery was $38.6 \pm 1.34$ weeks. In a study conducted by Lin et al and Kasai et al the age was similar to our study 39 weeks and 38 weeks respectively. ${ }^{15,25}$ Where as in the study by Bouzari et al the age was $35.83+3.61$ weeks which was lower than our study. ${ }^{26}$

The mean platelet count in present study was 106907.7 $\pm 30136.52 / \mu \mathrm{L}$. In the study conducted by Singh 
et al mean platelet count was $110320+21345.4 / \mu \mathrm{L}$ which was comparable to our study. ${ }^{11}$ Higher mean platelet count was seen in the studies conducted by Pourrat et al $(131000 / \mu \mathrm{L})$ and Jaleel et al $(122960+28146.5 / \mu \mathrm{L}) .{ }^{19,27}$

The mean neonatal platelet count was $175307.7+33834.87 / \mu \mathrm{L}$. The mean neonatal platelet count was lower than our study in Pourrat et al study $(122100 / \mu \mathrm{L}) .^{27}$ In the study of Yuce et al mean neonatal platelet count was $203000+12101.2 / \mu \mathrm{L}$ which was higher than our study. ${ }^{28}$

Table 10: Comparison of studies according to mean maternal platelet count.

\begin{tabular}{|c|c|c|c|}
\hline Study & $\begin{array}{l}\text { Platelet count } \\
\text { (lac/ } \mu \mathrm{L})\end{array}$ & $\begin{array}{l}P \\
\text { value }\end{array}$ & Significance \\
\hline Singh et $\mathrm{al}^{11}$ & $1,10,3200 \pm 21345.4$ & 0.000 & HS \\
\hline Jaleel et $\mathrm{al}^{19}$ & $1,22,960 \pm 28146.5$ & 0.021 & $\mathrm{~S}$ \\
\hline Present study & $1,06,907.7 \pm 30136.52$ & & \\
\hline
\end{tabular}

Table 11: Comparison of studies according to mean neonatal platelet count.

\begin{tabular}{|llll|}
\hline Study & $\begin{array}{l}\text { platelet count } \\
(\mathrm{lac} / \mathrm{\mu L})\end{array}$ & P value & Significance \\
\hline Yuce et $\mathrm{al}^{28}$ & $2,03,000 \pm 12101.2$ & 0.000 & HS \\
\hline Present study & $1,75,307.7 \pm 33834.87$ & \\
\hline
\end{tabular}

In present study incidence of fetal thrombocytopenia was $3.10 \%$ (p value 0.354 not statistically significant). In the study by Singh et al incidence was $1.09 \%$ which was similar to our study. ${ }^{11}$ The incidence of fetal thrombocytopenia was higher in the studies of Yuce et al (14\%), Yassaee et al (10.50\%) and Bhat et al (36.10\%) and difference were statistically significant. ${ }^{23,28}$

Table 12: Comparison of studies according to incidence of fetal thrombocytopenia.

\begin{tabular}{|llll|}
\hline Study & Incidence & P value & Significance \\
\hline Singh et $\mathrm{al}^{11}$ & $1.09 \%$ & 0.354 & NS \\
\hline${\text { Bhat et } \mathrm{al}^{23}}^{28}$ & $36.1 \%$ & 0.000 & $\mathrm{HS}$ \\
\hline Yuce et al $^{28}$ & $14 \%$ & 0.032 & $\mathrm{~S}$ \\
\hline Yassaee et al $^{29}$ & $10.5 \%$ & 0.223 & NS \\
\hline Present study & $3.1 \%$ & & \\
\hline
\end{tabular}

In the present study the association of thrombocytopenia with PIH was seen in $26.30 \%$ women, which was similar to the studies of Brohi et al $(26.70 \%)$, Singh et al (24.20\%), Vyas et al (22\%) Parnas et al (21.11\%) and Burrows et al $(21 \%) .^{9-11,14,21}$

In the present study HELLP syndrome was seen in $1.50 \%$ of the thrombocytopenic women which was statistically similar to the study by Turgot et al $(1.14 \%)$, Habas et al $(0.37 \%)$ and Vyas et al $(4.08 \%))^{9,18,19,30}$ Whereas studies by Parnas et al and Onisai et al showed HELLP syndrome in $12.06 \%$ and $9.52 \%$ women respectively, which was higher than our study. ${ }^{13,21}$

Table 13: Distribution of subjects according to association with PIH.

\begin{tabular}{|c|c|c|c|}
\hline Study & $\begin{array}{l}\text { Association } \\
\text { with PIH }\end{array}$ & P value & Significance \\
\hline${\text { Vyas et } \mathrm{al}^{9}}^{9}$ & $22 \%$ & 0.455 & NS \\
\hline Burrows et al ${ }^{10}$ & $21 \%$ & 0.347 & NS \\
\hline Singh et $\mathrm{al}^{11}$ & $24.2 \%$ & 0.780 & NS \\
\hline Onisai et al ${ }^{13}$ & $21.15 \%$ & 0.453 & NS \\
\hline${\text { Brohi et } \mathrm{al}^{14}}^{14}$ & $26.7 \%$ & 0.936 & NS \\
\hline Parnas et $\mathrm{al}^{21}$ & $21.11 \%$ & 0.396 & NS \\
\hline Present study & $26.3 \%$ & & \\
\hline
\end{tabular}

Table 14: Comparison of studies according to association with HELLP syndrome.

\begin{tabular}{|c|c|c|c|}
\hline Study & $\begin{array}{l}\text { Association } \\
\text { with HELLP }\end{array}$ & $\begin{array}{l}P \\
\text { value }\end{array}$ & Significance \\
\hline Vyas et al $^{9}$ & $4.8 \%$ & 0.300 & NS \\
\hline Onisai et $\mathrm{al}^{13}$ & $9.52 \%$ & 0.038 & $\mathrm{~S}$ \\
\hline Turgot et al ${ }^{18}$ & $1.14 \%$ & 0.762 & NS \\
\hline Parnas et $\mathrm{al}^{21}$ & $12.06 \%$ & 0.012 & $\mathrm{~S}$ \\
\hline Habas et $\mathrm{al}^{30}$ & $0.37 \%$ & 0.203 & NS \\
\hline Present study & $1.5 \%$ & & \\
\hline
\end{tabular}

In present study incidence of ITP was 3\% amongst pregnant thrombocytopenic women. In the study conducted by Burrows et al incidence was similar to our study $(3 \%) \mathrm{p}$ value - 0.945 . In the study conducted by Singh et al the incidence of ITP was $8.40 \%$ but it was also not statistically significant ( $\mathrm{p}$ value 0.170$).{ }^{11}$

In our study $27.70 \%$ of subjects had delivered by LSCS and $72.30 \%$ patient delivered vaginally which was similar to study by Singh et al (LSCS 36\% and FTNVD 64\%) and Vyas et al (LSCS 37\% and FTNVD 63\%) and Ruggri et al (LSCS 20\% and FTNVD 80\%). ${ }^{9,11,20}$ Whereas the incidence of LSCS was higher in the studies conducted by Pafumi et al (55\%) and Yuce et al $(56 \%){ }^{28,31}$

In the present study $4.60 \%$ subjects required blood transfusion. However, the need for blood transfusion was higher in the studies by Parnas et al (16.60\%), Borna et al $(26.20 \%)$, Yuce et al $(10 \%)$ and Dwivedi et al $(9.0 \%)^{8,17,21,28}$

In the present study, 30\% of thrombocytopenic women required induction of labour for various obstetrical indications. In the study by Parnas et al $27.20 \%$ women required induction of labour which was comparable to our study ( $\mathrm{p}$ value 0.571 statistically non-significant). ${ }^{21}$

The mean neonatal weight in our study was $2.80+0.32 \mathrm{~kg}$. In the study by Onisai et al the mean neonate weight was $2.9 \pm 0.23 \mathrm{~kg}$ which was similar to our study. ${ }^{13}$ Whereas 
the mean weight was lower in study by Bouzari et al $(2.58 \pm-8.0 \mathrm{~kg}){ }^{26}$

In our study $6.15 \%$ neonates required NICU admissions. In the study conducted by Vyas et al $13.20 \%$ neonates were admitted to NICU. ${ }^{9}$ In the study by Lin et al, $0.30 \%$ neonates required NICU admission which is very low as compare to our study. ${ }^{15}$

In our study $6.15 \%$ neonates had APGAR score less than 7 at 5 minutes which is comparable to the study by Parnas et al in which only $2.4 \%$ of neonates had lower APGAR score. ${ }^{21}$ In the study by Lin et al $0.3 \%$ Neonate had APGAR score $<7$ at 5 minutes which is significantly lower as compare to our study. ${ }^{15}$ Kasai et al also did not report any neonate with APGAR score $<7$ at 5 minute. ${ }^{25}$

In our study $8 \%$ of neonates were small for gestational age which was similar to a study conducted by Yuce et al in which $6.50 \%$ neonates were SGA. ${ }^{28}$

\section{CONCLUSION}

The normal range of platelet count in non-pregnant women is $1,50,000 / \mu \mathrm{L}$ to $4,00,000 / \mu \mathrm{L}$. It decreases in pregnancy $(2,15,000 / \mu \mathrm{L})$

In our study the incidence of thrombocytopenia was $8.4 \%$. Gestational thrombocytopenia was the commonest cause with incidence of $68.2 \%$, followed by PIH (26.3\%), ITP $(3 \%)$ and HELLP syndrome (1.5\%).

Gestational thrombocytopenia is the commonest cause of thrombocytopenia and may not be related to adverse pregnancy outcome, thus can be treated as benign condition. Clinical assessment is the most important factor for evaluating a patient with thrombocytopenia. A detailed history including previous or current bleeding problem, family history, past obstetrics history, drug abuse and blood transfusion history is important.

A careful examination and simple laboratory test are needed so that a serious condition that may require specific and urgent management (examples HELLP syndrome, severe pre-eclampsia, TTP, HUS and acute fatty liver of pregnancy) is not missed.

Monitoring of platelet count of mother should be a routine at antenatal visits for timely diagnosis and to achieve favourable feto-maternal outcome in all types of thrombocytopenia. Neonatal platelet count should be done in all mothers diagnosed with thrombocytopenia.

Funding: No funding sources Conflict of interest: None declared

Ethical approval: The study was approved by the Institutional Ethics Committee

\section{REFERENCES}

1. Kadir RA, McLintock C. Thrombocytopenia and disorders of platelet function in pregnancy. Semin Thromb Hemost. 2011;37:640-52.

2. McCarae KR. Thrombocytotenia in pregnancy. Hematology Am Soc Hematol Educ Program. 2010;397-402.

3. Lewis SM, Bain BJ, Bates I. Practical haematology, Elsevier $10^{\text {th }}$ edi; 2006:14-5.

4. Shehata N, Burrow R, Kelton JG. Gestational thrombocytopenia. Clin Obst Gynaecol. 1999;42:327-34.

5. Burrows RF, Kelton JG. Thrombocytopenia at delivery: a prospective survey of 6715 deliveries. Am J O Obstet. Gynecol. 1990;162:731-4.

6. Sullivan CA, Martin JN. Management of obstetric patient with thrombocytopenia. Clin Obstet Gynecol. 1995;38:521-34.

7. Mc Carae KR. Thrombocytotenia in pregnancy. Hematology Am Soc Hematol Educ Program. 2010;397-402.

8. Dwivedi P, Puri M, Nigam A, Agarwal K. Fetomaternal outcome in pregnancy with severe thrombocytopenia. Eur Rev Med Pharmacol Sci. 2012;16(11):1563-6.

9. Vyas R, Shah S, Yadav P, Patel U. Comparative study of mild versus moderate to severe thrombocytopenia in third trimester of pregnancy in a tertiary care hospital. NHL Journal of Medical Sciences. 2014;3(1):8-11.

10. Burrows RF, Kelton JG. Thrombocytopenia at delivery: a prospective survey of 6715 deliveries. Am J Obstet Gynecol. 1990;162(3):731-4.

11. Singh N, Amita D, Uma S, Tripathi AK, Pushplata S. Prevalenceand characterization of thrombocytopenia in pregnancy in Indian women. Indian $\mathrm{J}$ Hematol Blood Transfus. 2012;28(2):77-81.

12. Ajibola SO, Akinbami A, Rabiu K, Adewunmi A, Dosunmu A, Adewumi A. Gestational thrombocytopaenia among pregnant women in Lagos Nigeria. Niger Med J. 2014;55(2):139-43.

13. Onisai M, Vladareanu AM, Delcea C, Ciorascu M, Bumbea H, Nicolescu A. Perinatal outcome for pregnancies complicated with thrombocytopenia. J Matern Fetal Neonatal Med. 2012;25(9):1622-6.

14. Brohi ZP, Perveen U, Sadaf A. Thrombocytopenia in pregnancy: an observational study. Pak J Med. 2013;52(3):67-70.

15. Lin YH, Lo LM, Hsieh CC, Chiu TH, Hsieh TT, Hung TH. Perinatal outcome in normal pregnant women with incidental thrombocytopenia at delivery. Taiwan J Obstet Gynecol. 2013;52(3):347-50.

16. Suri V, Aggarwal N, Saxena S, Malhotra P, Varma $\mathrm{S}$. Maternal and perinatal outcome in idiopathic thrombocytopenic purpura (ITP) with pregnancy. Acta Obstet Gynecol Scand. 2006;85(12):1430-5.

17. Borna S, Borna $\mathrm{H}$, Khazardoost S. Maternal and neonatal outcomes in pregnant women with immune 
thrombocytopenic purpura. Arch Iran Med. 2006;9(2):115-8.

18. Turgut A, Demirci O, Demirci E, Uludoğan $M$. Comparison of maternal and neonatal outcomes in women with HELLP syndrome and women with severe preeclampsia without HELLP syndrome. J Prenat Med. 2010;4(3):51-8.

19. Jaleel A, Baseer A. Thrombocytopenia in preeclampsia: an earlier detector of HELLP syndrome. J Pak Med Assoc. 1997;47(9):230-2.

20. Ruggeri M, Schiavotto C, Castaman G, Tosetto A, Rodeghiero F. Gestational thrombocytopenia: a prospective study. Haematologica. 1997;82(3):341-2.

21. Parnas M, Sheiner E, Shoham-Vardi I, Burstein E, Yermiahu T, Levi I, et al. Moderate to severe thrombocytopenia during pregnancy. Eur J Obstet Gynecol Reprod Biol. 2006;128(1-2):163-8.

22. Nazli R, Khan MA, Aakhtar T, Mohammad NS, Aslam H, Haider J. Frequency of thrombocytopenia in pregnancy related hypertensive disorders in patients presenting at tertiary care hospitals of Peshawar. KMUJ. 2012;4(3):101-5.

23. Bhat YR, Cherian CS. Neonatal thrombocytopenia associated with maternal pregnancy induced hypertension. Indian J Pediatr. 2008;75(6):571-3.

24. Won YW, Moon W, Yun YS, Oh HS, Choi JH, Lee YY, et al. Clinical aspects of pregnancy and delivery in patients with chronic idiopathic thrombocytopenic purpura. Korean J Intern Med. 2005;20(2):129-34.

25. Kasai J, Aoki S, Kamiya N, Hasegawa Y, Kurasawa $\mathrm{K}$, Takahashi T, et al. Clinical features of gestational thrombocytopenia difficult to differentiate from immune thrombocytopenia diagnosed during pregnancy. J Obstet Gynaecol Res. 2015;41(1):44-9.

26. Bouzari Z, Firoozabadi S, Hasannasab B, Emamimeybodi S, Golsorkhtabar-Amiri M. Maternal and neonatal outcomes in HELLP syndrome, partial HELLP syndrome and severe pre-eclampsia: eleven years' experience of an obstetric center in the North of Iran. World Applied Sciences Journal. 2013;26(11):1459-63.

27. Pourrat O, Valère G, Pierre F. Is incidental gestational thrombocytopaenia really always safe for the neonate? J Obstet Gynaecol. 2014;34(6):499-500.

28. Yuce T, Acar D, Kalafat E, Alkilic A, Cetindag E, Soylemez F. Thrombocytopenia in pregnancy: do the time of diagnosis and delivery route affect pregnancy outcome in parturients with idiopathic thrombocytopenic purpura? Int J Hematol. 2014;100(6):540-4.

29. Yassaee F, Eskandari R, Amiri Z. Pregnancy outcomes in women with idiopathic thrombocytopenic purpura. Iran $\mathbf{J}$ Reprod Med. 2012;10(5):489-92.

30. Habas E, Rayani A, Ganterie R. Thrombocytopenia in hypertensive disorders of pregnancy. J Obstet Gynaecol India. 2013;63(2):96-100.

31. Pafumi C, Valenti O, Giuffrida L, Colletta G. Gestational thrombocytopenia: does it cause any maternal and /or perinatal morbidity? Cukurova Med J. 2013;38(3):349-57.

Cite this article as: Chauhan V, Gupta A, Mahajan N, Vij A, Kumar R, Chadda A. Maternal and fetal outcome among pregnant women presenting with thrombocytopenia. Int J Reprod Contracept Obstet Gynecol 2016;5:2736-43. 